\title{
Cetuximab enhances the effect of oxaliplatin on hypoxic gastric cancer cell lines
}

\author{
HUI-YAN LUO ${ }^{1 *}$, WEI WEI ${ }^{2 *}$, YAN-XIA SHI ${ }^{1}$, XIAO-QIN CHEN ${ }^{1}$, YU-HONG LI $^{1}$, \\ FENG WANG ${ }^{1}$, MIAO-ZHEN QIU ${ }^{1}$, FANG-HUA LI ${ }^{1}$, SHU-LI YAN ${ }^{3}$, \\ MU-SHENG ZENG ${ }^{4}$, PENG HUANG ${ }^{5}$ and RUI-HUA XU ${ }^{1}$
}

\begin{abstract}
${ }^{1}$ State Key Laboratory of Oncology in Southern China and Department of Medical Oncology; ${ }^{2}$ State Key Laboratory of Oncology in Southern China and Department of Hepatobiliary Oncology; ${ }^{3}$ State Key Laboratory of Oncology in Southern China and Department of Laboratory; ${ }^{4}$ State Key Laboratory of Oncology in Southern China and

Department of Experimental Research, Sun Yat-Sen University Cancer Center, Guangzhou, P.R. China; ${ }^{5}$ Department of Molecular Pathology, The University of Texas, MD Anderson Cancer Center, Houston, TX, USA
\end{abstract}

Received January 18, 2010; Accepted March 12, 2010

DOI: $10.3892 /$ or_00000819

\begin{abstract}
Hypoxia is recognized as an important factor contributing to cancer development and drug resistance. Cetuximab, a chimeric monoclonal antibody to EGFR, is known to inhibit HIF-1 $\alpha$ expression levels and to enhance the cytotoxicity of chemotherapeutic agents. We demonstrated that hypoxia induced drug resistance in gastric cancer cells. Cetuximab enhanced oxaliplatin-induced cytotoxicity and apoptosis in normoxia and caused a reversal of drug resistance in hypoxia. Normoxic and hypoxic gastric cancer cells were treated with cetuximab, oxaliplatin or the combination and assessed for cell growth, proliferation, and apoptosis. Combination treatment resulted in a marked inhibition of HIF-1 $\alpha$ expression levels in hypoxic cells and caused a significant reduction in the expression of activated phosphorylated AKT, ERK1/2, p-BAD and VEGF in both normoxia and hypoxia with greater levels of inhibition in hypoxia. In summary, cetuximab inhibits HIF-1 $\alpha$ expression via the MAPK/ERK and PI3K/AKT signaling pathways and functions
\end{abstract}

Correspondence to: Dr Rui-hua Xu, Department of Medical Oncology, Sun Yat-Sen University Cancer Center, 651 Dong Feng Road East, Guangzhou 510060, P.R. China

E-mail: xurh@mail.sysu.edu.cn

Dr Peng Huang, Department of Molecular Pathology, The University of Texas, MD Anderson Cancer Center, Box 89, 1515 Holcombe Blvd., Houston, TX 77030, USA

E-mail: phuang@mdanderson.org

${ }^{*}$ Contributed equally

Key words: hypoxia, gastric cancer, hypoxia-inducible factor-1 $\alpha$, drug resistance, MAPK/ERK signaling pathways, PI3K/AKT signaling pathway to overcome drug resistance induced by hypoxia. Cetuximaboxaliplatin combination therapy may therefore emerge as an attractive treatment strategy for advanced gastric cancer.

\section{Introduction}

Gastric cancer is the fourth most common cancer worldwide and the second leading cause of cancer-related death in the world (1) with the highest incidence reported in Japan, Korea and China (2). The only potentially curative treatment for local gastric cancer is surgery. However, most cases of gastric cancer present at an advanced stage where the only possible management of the disease is via chemotherapy. The rapid development of new chemotherapeutic agents have done little to improve the prognosis of advanced and recurrent gastric cancer, with response rates ranging from 20 to $50 \%$ and the overall 5-year survival rates range from 5 to $15 \%$ (3). It is evident that new treatment options are urgently needed.

Hypoxia has been recognized as a common environmental stress contributing to the development of various malignancies. Hypoxia-inducible factor-1 (HIF-1) is the main regulatory protein in the cellular response to decreased oxygen levels $(4,5)$. HIF-1 is a heterodimeric transcription factor (consisting of $\alpha$ and $\beta$ subunits) that regulates the expression of genes involved in angiogenesis, cell proliferation and metabolism and drug sensitivity (6-8). The inducible $\alpha$ subunit is upregulated in hypoxia and plays an integral role in the body's response to hypoxia by increasing vascularization in hypoxic areas and promoting homeostasis. The $\beta$ subunit is constitutively expressed (9). In normoxia, HIF-1 $\alpha$ is hydroxylated by prolyl hydroxylase 2 (PHD2) and ubiquitinated by the von Hippel Lindau protein (VHL) thereby being targeted to the proteosomes for degradation. However, prolyl hydroxylation is inhibited in a hypoxic microenvironment, resulting in stabilization of the HIF- $1 \alpha$ subunit which then translocates to the nucleus. HIF-1 $\alpha$ subsequently dimerizes with the B subunit and transcriptionally activates a number of genes by binding to hypoxia-responsive elements (HREs) in their promoters (10-13). HIF-1 $\alpha$ expression correlates with a poor 
prognosis and an inefficient response to treatment in a number of cancers including gastric cancer $(14,15)$.

HIF-1 $\alpha$ is also regulated by several non-oxygen-dependent mechanisms such as the activation of different oncogenes and the inactivation of tumor suppressor genes such as PAS, MYC, PTEN and VHL $(11,16)$. Cytokines, epidermal growth factor (EGF) and insulin-like growth factor (IGF) are also known to play a role in the synthesis and functioning of HIF-1 $\alpha$ via the activation of phosphatidylinositol 3-kinase (PI3-K)/ AKT or mitogen-activated protein kinase (MAPK) pathways (17-19). The activation of PI3-K/AKT resulted in elevated HIF-1 $\alpha$ protein levels while activation of the MAPK pathway resulted in increased transactivation by HIF-1 $\alpha$.

The epidermal growth factor receptor (EGFR), a member of the ErbB receptor family, is often overexpressed in a variety of human tumors with epithelial origin, including breast, gastric, colorectal, and non-small cell lung cancer (20). EGFR, a $170-\mathrm{kDa}$ transmembrane glycoprotein with intrinsic tyrosine kinase activity, consists of an extracellular ligand binding domain, a transmembrane region, and an intracellular tyrosine protein kinase domain (21). Overexpression of EGFR was associated with resistance to cytotoxic drugs and poor prognosis in cancer patients. The two major downstream signaling pathways of EGFR are 1) the Ras-Raf-MAPK pathway, which contributes to cell proliferation, survival, and transformation, and 2) the phosphatidylinositol 3-kinase $(\mathrm{PI} 3-\mathrm{K})$ and the downstream protein-serine/threonine kinase AKT. Activation of AKT triggers a cascade of responses from cell growth and proliferation to survival and motility (22). These two signaling pathways lead to elevated HIF-1 $\alpha$ levels $(18,19)$.

Two recent strategies to target EGFR are 1) monoclonal antibodies directed at the ligand-binding extracellular domain which block ligand binding and receptor activation; and 2) small molecule tyrosine kinase inhibitors that compete with ATP for binding to the tyrosine kinase domain of the receptor $(8,23)$. Cetuximab (C225, Erbitux) is a chimeric monoclonal antibody directed to the extracellular domain of EGFR. Numerous studies have shown that cetuximab inhibited the production of vascular endothelial growth factor (VEGF) in vitro and in vivo by inhibiting HIF- $1 \alpha$ expression levels (24-28).

Oxaliplatin, a third generation platinum analog which has been extensively used to treat colorectal cancer, works by generating bulky platinum-DNA adducts that are poorly recognized by the mismatch repair system (29). A major drawback to using oxaliplatin-based therapy is the development of drug resistance similar to other platinum-based therapies. Cetuximab was shown to enhance the cytotoxicity of chemotherapeutic agents such as oxaliplatin, doxorubicin, paclitaxel, cisplatin, and topotecan on tumor xenografts derived from a variety of human cancer cells $(30,31)$. In colorectal cancer, cetuximab potentiated DNA damage caused by oxaliplatin and combination treatment resulted in an enhanced anti-tumor effect (29).

Based on the above findings, we investigated the effect of cetuximab-oxaliplatin combination treatment on drug resistance and apoptosis in hypoxic gastric cancer cell lines and interrogated the molecular mechanisms of cetuximab-mediated inhibition of the EGFR signaling pathway leading to inhibition of HIF-1 $\alpha$ levels and enhanced apoptosis. We demonstrated a significant downregulation in the levels of HIF-1 $\alpha$, pERK1/2, pAKT and pBAD (important survival signals) in oxaliplatincetuximab-treated gastric cancer cells, especially under hypoxic conditions. Cetuximab, which enhances the chemotherapeutic potential of oxaliplatin, thus emerges as an attractive new candidate in the treatment of gastric cancer and functions to circumvent drug resistance and increase apoptosis in these cells.

\section{Materials and methods}

Chemicals and reagents. Monoclonal antibody to EGFR (cetuximab C225) (2 mg/ml) was purchased from Merck (Darmstadt, Germany). Oxaliplatin $(5 \mathrm{mg} / \mathrm{ml})$ was purchased from Sanofi Synthelabo (Gentilly, France). Mouse monoclonal phospho-ERK1/2 antibody $\left(\mathrm{Thr}^{202} / \mathrm{Tyr}^{204}\right.$ ), rabbit polyclonal ERK1/2 antibody, rabbit polyclonal phosphor-AKT antibody $\left(\mathrm{Ser}^{473}\right)$, and rabbit polyclonal AKT antibody were all from Cell Signaling Technology Inc. (Beverly, MA, USA). Mouse monoclonal BAX antibody, rabbit polyclonal BAD antibody and rabbit polyclonal phospho-BAD ( $\mathrm{Ser}^{112}$ ) antibody were from Santa Cruz Biotechnology (Santa Cruz, CA, USA). Mouse monoclonal antibody against human HIF-1 $\alpha$ was from BD Biosciences (San Jose, CA, USA).

Cell culture. Human gastric cell lines MGS-803 and SGC-7901 (kindly provided by the State Key Laboratory of Oncology in southern China and Department of Laboratory, China) were routinely cultured in RPMI-1640 medium (Invitrogen, CA, USA) supplemented with $10 \%$ new born calf serum (Invitrogen), $100 \mathrm{U} / \mathrm{ml}$ of penicillin and $100 \mu \mathrm{g} / \mathrm{ml}$ streptomycin (ICN, Irvine, UK) at $37^{\circ} \mathrm{C}$ in humidified air with $5 \%$ $\mathrm{CO}_{2}$. Hypoxia was achieved by incubating cells in a sealed modular incubator chamber (Billups-Rothenberg, Del Mar, CA) flushed with $1 \% \mathrm{O}_{2}, 4 \% \mathrm{CO}_{2}$ and $95 \% \mathrm{~N}_{2}$.

Assays of cell growth and cytotoxicity. Cell growth inhibition was determined by directly counting the cells 24,48 and $72 \mathrm{~h}$ after they were treated with cetuximab alone, oxaliplatin alone, or the combination. For combination treatment, cells were treated with cetuximab for $12 \mathrm{~h}$ prior to the addition of oxaliplatin. We found no significant difference between this regimen and simultaneous treatment with both drugs. Cell cytotoxicity was determined using the 3-(4,5-dimethylthiazol2-yl)-2,5-diphenyltetrazolium (MTT) bromide assay. Briefly, cells were seeded onto 96-well plates at a density of 4000 cells per well, incubated for $12 \mathrm{~h}$ to ensure attachment and then treated with cetuximab $(0.25-100 \mu \mathrm{g} / \mathrm{ml})$ and/or oxaliplatin $(0.5-200 \mu \mathrm{M})$. After $72 \mathrm{~h}$ of treatment, the cells were treated with $5 \mathrm{mg} / \mathrm{ml}(20 \mu \mathrm{l} /$ well $)$ of MTT reagent and incubated for $4 \mathrm{~h}$. The supernatant was removed and cell pellets were dissolved in $200 \mu \mathrm{l}$ DMSO. Absorbance was determined using a MultiSkan plate reader (LabSystems, Helsinki, Finland) at a wavelength of $540 \mathrm{~nm}$.

Apoptosis assays. Apoptosis was quantified by flow cytometry using the Annexin V-FITC and propidium iodide (PI) Apoptosis kit (Keygen Biotech, Nanjing, China) as follows: Cells that were treated with the different combinations of 
cetuximab and oxaliplatin were collected, washed with cold PBS, and then suspended in Annexin-V-binding buffer solution. The cells were stained with Annexin V-FITC for 15 min at room temperature and then stained with PI. The samples were analyzed using a FACSCalibur flow cytometer equipped with Cell Quest-Pro software (Becton-Dickinson, San Jose, CA, USA). Each experiment was performed thrice with consistent results.

\section{Drug interaction analysis}

Combination index (CI) calculations. Cells were treated with oxaliplatin and cetuximab as described above. The cytotoxic effects obtained with oxaliplatin and cetuximab combinations were analyzed as described (32). Briefly, we determined the median inhibitory concentration $\left(\mathrm{IC}_{50}\right)$ for each drug in a fixed-ratio combination of the two drugs. For two drugs acting by mechanisms that are not mutually exclusive, the CI (combination index value) was calculated using the following formula: $\mathrm{CI}=\mathrm{D}_{1} /\left(\mathrm{IC}_{50}\right)_{1}+\mathrm{D}_{2} /\left(\mathrm{IC}_{50}\right)_{2}+\left(\mathrm{D}_{1} \mathrm{xD} \mathrm{D}_{2}\right) /\left[\left(\mathrm{IC}_{50}\right)_{1} \mathrm{x}\left(\mathrm{IC}_{50}\right)_{2}\right]$. $\mathrm{D}_{1}$ and $\mathrm{D}_{2}$ are calculated from the $\mathrm{IC}_{50}$ for the combination and the ratio $(\mathrm{P} / \mathrm{Q})$ of the two drugs as follows: $\mathrm{D}_{1}=\left(\mathrm{IC}_{50}\right)$ comb $\times \mathrm{P} /(\mathrm{P}+\mathrm{Q})$ and $\mathrm{D}_{2}=\left(\mathrm{IC}_{50}\right)$ comb $\times \mathrm{Q} /(\mathrm{P}+\mathrm{Q})$. The third (interaction) term is absent when the drug actions are mutually exclusive. For each drug combination in our study we used the Calcusyn software (Biosoft, Ferguson, MO) to calculate the $\mathrm{CI}$ for 4 concentrations (2:1 ratio) of the two drugs and averaged the CIs. A CI of 1 indicates additive effects, whereas a $\mathrm{CI}<1$ indicates synergy.

Immunoblotting. In order to assess the expression of HIF- $1 \alpha$, ERK, phosphorylated ERK1/2, AKT and phosphorylated AKT proteins, cells were solubilized in lysis buffer $(50 \mathrm{mM}$ Tris-HCl, pH 6.8, $10 \%$ glycerol, $2 \%$ SDS, $0.1 \%$ bromophenol blue, $2.5 \%$ B-mercaptoethanol). Total protein concentration of whole cell lysates was determined using BioRad BCA method (Pierce, Rockford, IL, USA). Equal amounts of protein were electrophoresed on 7.5-10\% sodium dodecyl sulfate (SDS)polyacrylamide gels and electroblotted onto nitrocellulose membranes (Hybond ECL, Amersham Pharmacia). After blocking with Tris-buffered saline (TBS)/5\% skim milk or $5 \% \mathrm{BSA}$, the membranes were incubated overnight at $4^{\circ} \mathrm{C}$ with mouse monoclonal antibodies against human HIF- $1 \alpha$, BAX, or phosphorylated ERK1/2 or rabbit antibodies against total ERK, AKT, BAD, phosphorylated ERK1/2, AKT $\left(\mathrm{Ser}^{473}\right)$ and $\mathrm{BAD}\left(\mathrm{Ser}^{112}\right)$. The membranes were washed, incubated with a horseradish peroxidase (HRP) conjugated goat antimouse IgG (1:5000) or goat anti-rabbit (1:2000) (Cell Signaling Technology Inc.) for $1 \mathrm{~h}$ at room temperature, and visualized using enhanced chemiluminescence (ECL). Equal loading was verified by immunoblotting with a GAPDH antibody (Santa Cruz Biotechnology).

ELISA assay for VEGF. VEGF protein levels in the conditioned media were assayed using the Quantikine/Human VEGF ELISA kit (R\&D Systems Inc., Minneapolis, MN) according to the manufacturer's protocol. Briefly, cells were seeded onto 12-well plates at a density of $2 \times 10^{5}$ per well and incubated $12 \mathrm{~h}$ to ensure attachment. The cells were treated with cetuximab $(50 \mu \mathrm{g} / \mathrm{ml})$, oxaliplatin $(100 \mu \mathrm{M}, 200 \mu \mathrm{M})$ or a combination of the two drugs for 24 or $48 \mathrm{~h}$ as described
Table I. Sensitivity of human gastric cancer cells to oxaliplatin and cetuximab under normoxic and hypoxic conditions determined by the MTT assay.

\begin{tabular}{lcccc}
\hline & & \multicolumn{2}{c}{$\mathrm{IC}_{50}(95 \%$ confidence intervals $)$} & \\
\cline { 3 - 4 } Cell & Status & Oxal & C225 + Oxal & $\begin{array}{c}\text { Enhance } \\
\text { index }\end{array}$ \\
\hline \multirow{2}{*}{ MGC803 } & $\mathrm{N}$ & $5.76(4.09-8.12)$ & $3.20(2.48-4.14)$ & 1.80 \\
& $\mathrm{H}$ & $20.55(12.93-32.65)$ & $7.87(5.24-11.82)$ & 2.61 \\
SGC7901 & $\mathrm{N}$ & $4.98(3.49-7.11)$ & $3.08(2.35-4.02)$ & 1.61 \\
& $\mathrm{H}$ & $10.79(8.63-13.50)$ & $3.81(2.54-5.73)$ & 2.83 \\
\hline
\end{tabular}

Comparison of $\mathrm{IC}_{50}(\mu \mathrm{M})$ of oxaliplatin alone and oxaliplatin combined with cetuximab, on MGC803 cells and SGC7901 cells under normoxic (N) and hypoxic $(\mathrm{H})$ conditions. Data are expressed as mean \pm SEM and represent the average of four different experiments. Combination index of oxaliplatin and cetuximab in MGC803 and SGC7901 cells under normoxic and hypoxic conditions were calculated using the Median Dose-Effect program by Chou and Hayball.

above. The supernatants were collected and cells were counted in each well. The concentration of VEGF in the supernatant (100 $\mu \mathrm{l}$ ) was determined and normalized by the cell numbers. A serial dilution of human recombinant VEGF was included in each assay to obtain a standard curve.

\section{Results}

Cetuximab-oxaliplatin combination treatment inhibited cell growth in hypoxic gastric cancer cells. We evaluated the effect of cetuximab alone, oxaliplatin alone and combination treatment on growth of gastric cancer cell lines. Normoxic and hypoxic MGC803 and SGC7901 gastric cancer cells were treated with cetuximab $(50 \mu \mathrm{g} / \mathrm{ml})$, oxaliplatin $(100 \mu \mathrm{M})$, or the combination and the number of cells were counted directly. We showed that hypoxia caused a mild inhibition of cell growth (Fig. 1). Treatment of these cells with oxaliplatin alone had a more potent inhibitory effect on normoxic cells than on hypoxic cells. Cetuximab, by itself, did not inhibit cell growth. However, oxaliplatin-cetuximab combination treatment resulted in a more efficient inhibition of cell growth than either agent used alone. This effect was more potent in hypoxic cells than in normoxic cells.

Additionally, we used the MTT assay to evaluate the cytotoxic activity of cetuximab and oxaliplatin administrated alone or in combination on normoxic and hypoxic gastric cancer cell lines. Cetuximab alone was neither cytotoxic nor cytostatic even at $1000 \mu \mathrm{g} / \mathrm{ml}$ (data not shown). Oxaliplatin had an $\mathrm{IC}_{50}$ of $5.76 \mu \mathrm{M}$ in normoxic MGC803 cells and $4.98 \mu \mathrm{M}$ in normoxic SGC7901 cells. However, the $\mathrm{IC}_{50}$ of oxaliplatin decreased by $44.4 \%$ in MGC803 cells and 38.2\% in SGC7901 cells (Table I) when combined with cetuximab. Oxaliplatin had an $\mathrm{IC}_{50}$ of $20.55 \mu \mathrm{M}$ in hypoxic MGC803 cells and $10.79 \mu \mathrm{M}$ in hypoxic SGC7901 cells. However, the $\mathrm{IC}_{50}$ of oxaliplatin decreased by $61.7 \%$ in MGC803 cells and $64.7 \%$ in SGC7901 cells (Table I) when combined with cetuximab. We tested the combination of cetuximab and 
(a)

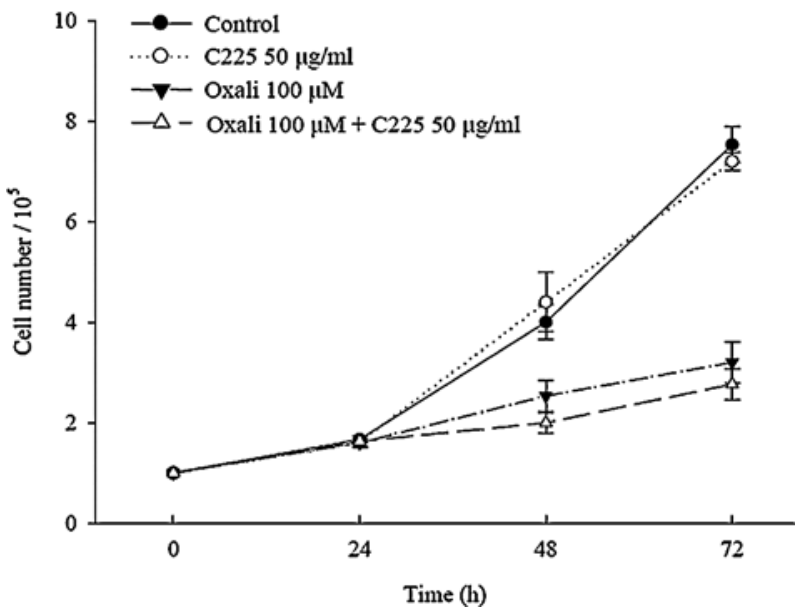

(c)

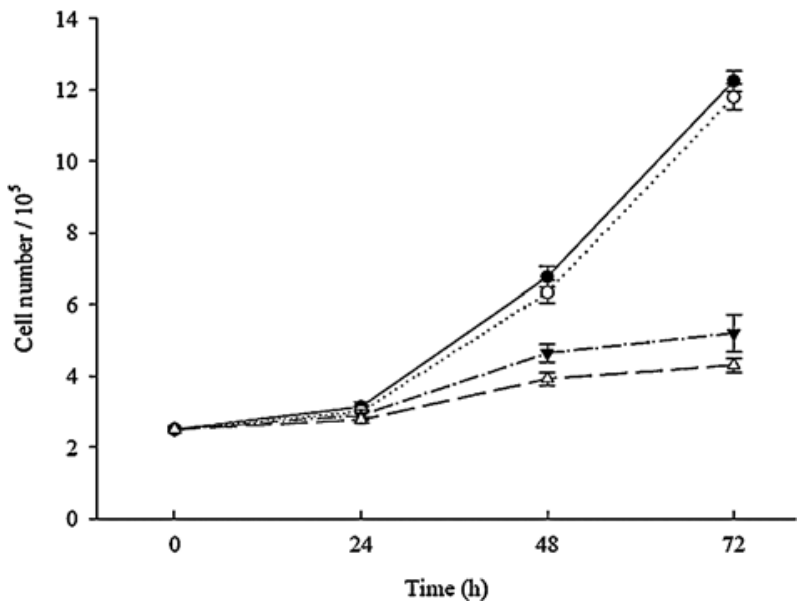

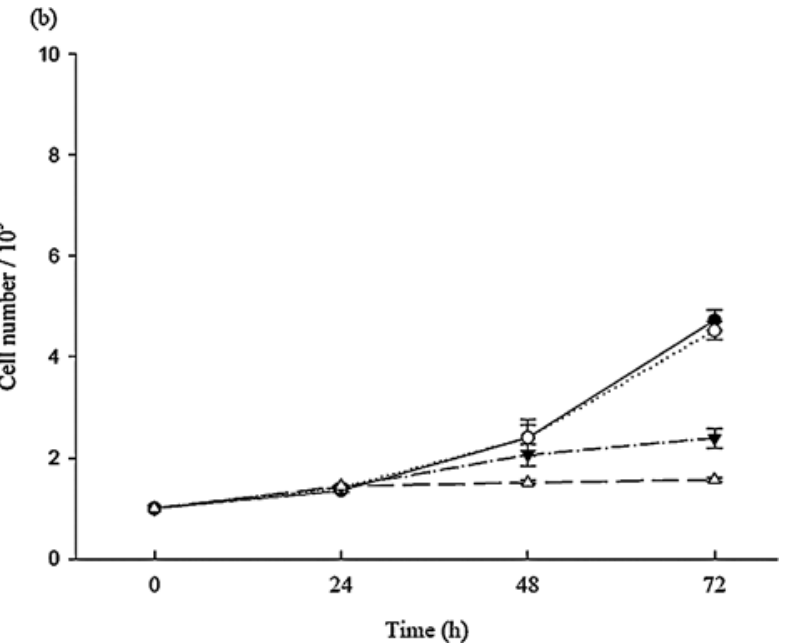

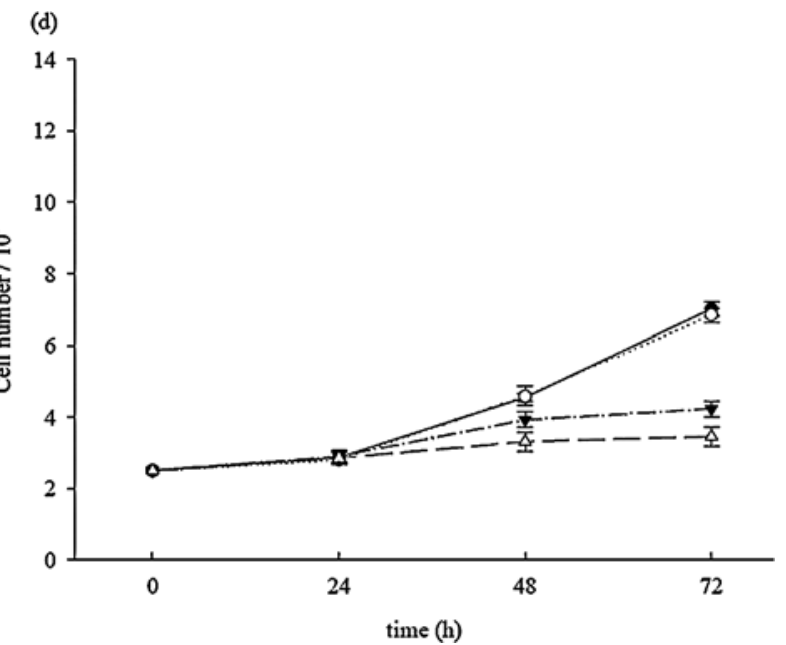

Figure 1. Growth inhibition by C225 and oxaliplatin in MGC-803 and SGC-7901 cells under normoxic and hypoxic conditions. (a) MGC 803 cell in normoxia, (b) MGC803 cell in hypoxia, (c) SGC7901 cell in normoxia, (d) SGC7901 cell in hypoxia. Data are mean \pm SD from four independent experiments. Cells were directly counted to determine total numbers at the indicated time points, $0,24,48$, and $72 \mathrm{~h}$. In normoxic MGC803 cells, the control group had significantly higher cell numbers than the oxaliplatin-treated group $(\mathrm{p}=0.001)$. Cell numbers in the $\mathrm{C} 225$-treated group were significantly higher than in the combination group $(\mathrm{p}<0.001)$; in the hypoxic group, $\mathrm{C} 225$-treated cells exhibited significantly higher cell numbers than the combination group ( $\mathrm{p}=0.001)$. The control group had significantly higher cell numbers than the oxaliplatin-treated group $(\mathrm{p}=0.014)$, but lower numbers than the $\mathrm{C} 225$-treated group ( $\mathrm{p}=0.021)$. In normoxic SGC7901 cells, the control group had significantly higher cell numbers than the oxaliplatin-treated group ( $\mathrm{p}=0.001)$, but less than C225-treated group ( $\mathrm{p}=0.003$ ) while the $\mathrm{C} 225$-treated group had significantly higher cell numbers than the combination group $(\mathrm{p}<0.001)$; hypoxic SGC7901 cells showed similar results with significantly higher cell numbers in the control group than in the oxaliplatin-treated group ( $\mathrm{p}=0.006)$. However, control cells had lower cell numbers than than the $\mathrm{C} 225$-treated group $(\mathrm{p}=0.010)$. The $\mathrm{C} 225$-treated group had significantly higher cell numbers than the combination group ( $<<0.001$ ).

irinotecan in normoxic and hypoxic gastric cancer cells and found similar results (data not shown).

These data showed that a) hypoxic gastric cancer cells were more resistant to the drug than normoxic cells, b) that cetuximab enhanced the cytotoxic effect of oxaliplatin in normoxia and hypoxia and c) that cetuximab enhanced the cytotoxic effect of oxaliplatin more efficiently in hypoxic cells than in normoxic cells (Table I).

Oxaliplatin and cetuximab act synergistically on gastric cancer cells. In order to quantitatively define the interaction between cetuximab and oxaliplatin on normoxic and hypoxic gastric cancer cells, we used a media-effect analysis program (32) to calculate the drug combination index (CI). The method uses mass action characteristics in order to quantitate the effect of multiple drugs in a system. CI is obtained by determining the fraction of cells affected and the concentration of drug required to produce a $50 \%$ effect. An additive effect would produce a $\mathrm{CI}$ value of 1 , whereas synergistic and antagonistic effects would produce CI values of $<1$ and $>1$, respectively. Gastric cancer cells were treated with various concentrations of oxaliplatin and cetuximab in a fixed ratio (2:1). The fractioneffect versus CI plots curves are displayed in Fig. 2. All the CI values were $<1$, demonstrating that the effects of the two drugs are synergistic. Furthermore, the CI values of treated hypoxic cells were lower than those of treated normoxic cells indicating that oxaliplatin and cetuximab exhibited more efficient synergy in hypoxia (Table II).

Hypoxic gastric cancer cells treated with cetuximab-oxaliplatin combination exhibited higher levels of apoptosis than cells treated with single agents. We investigated the effect of oxaliplatin-cetuximab combination treatment on the induction of programmed cell death in two different gastric cancer cell 
NORMOXIA

a

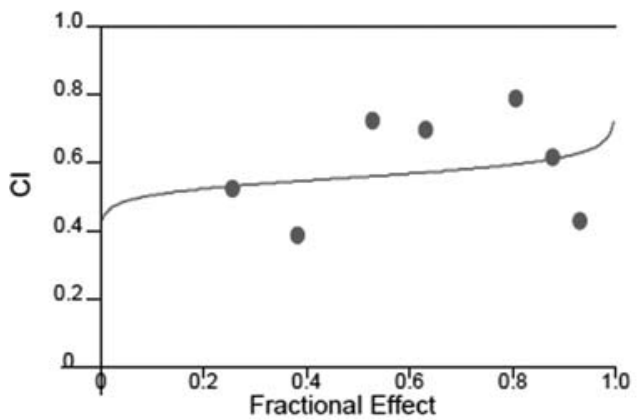

HYPOXIA

b

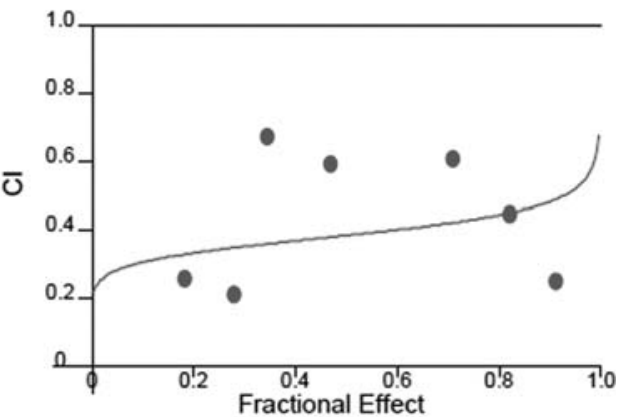

MGC 803 CELL

NORMOXIA

c

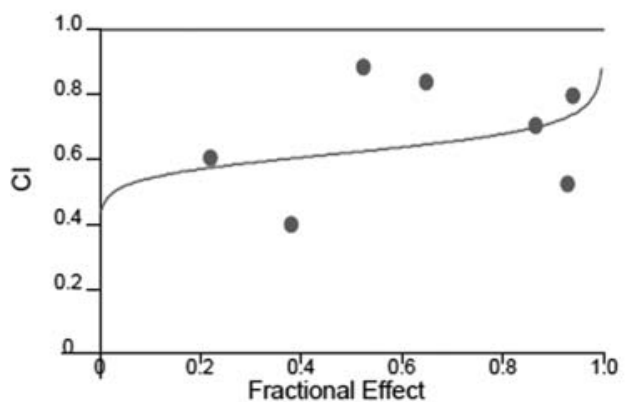

HYPOXIA

d

$\mathrm{L}+\mathrm{C}$ - Non-exclusive

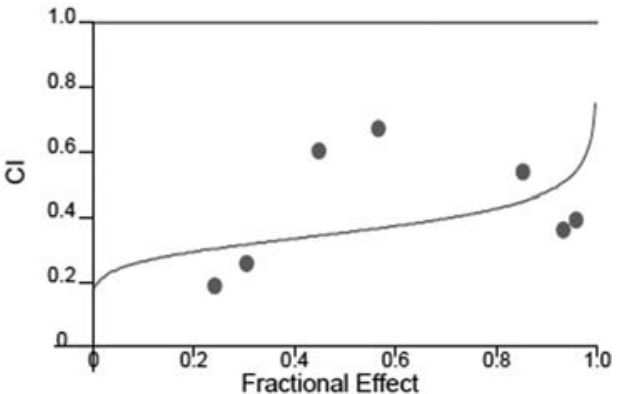

SGC 7901 CELL

Figure 2. Sensitivity of human gastric cancer cells to oxaliplatin and cetuximab determined by Median Dos-effect analysis. Median Dos-effect analysis reveals synergistic interactions in oxaliplatin-cetuximab-treated cells. Different concentrations of oxaliplatin and cetuximab were administered at a fixed ratio. Cell proliferation was determined by MTT assays after $72 \mathrm{~h}$. The Fa-CI curves were calculated using the Median Dos-Effect program by Chou and Hayball. Results for normoxic and hypoxic MGC803 cells are shown (a and b). Results for normoxic and hypoxic SGC7901 cells are shown (c and d).Values <1 indicate synergy and values $>1$ indicate partial antagonism.

Table II. Synergistic activity of oxaliplatin and cetuximab in human gastric cancer cells.

\begin{tabular}{|c|c|c|c|c|}
\hline \multirow[b]{2}{*}{ Cell } & \multirow{2}{*}{$\frac{\text { Oxaliplatin }}{(\mu \mathrm{M})}$} & \multirow{2}{*}{$\frac{\text { Cetuximab }}{(\mu \mathrm{g} / \mathrm{ml})}$} & \multicolumn{2}{|c|}{ Combination index } \\
\hline & & & Nomoxia & Hypoxia \\
\hline \multirow[t]{4}{*}{ MGC 803} & 5 & 2.5 & 0.722 & 0.672 \\
\hline & 10 & 5 & 0.695 & 0.592 \\
\hline & 50 & 25 & 0.789 & 0.605 \\
\hline & 100 & 50 & 0.615 & 0.447 \\
\hline \multirow[t]{4}{*}{ SGC 7901} & 5 & 2.5 & 0.881 & 0.605 \\
\hline & 10 & 5.0 & 0.837 & 0.673 \\
\hline & 50 & 25 & 0.705 & 0.540 \\
\hline & 100 & 50 & 0.522 & 0.362 \\
\hline
\end{tabular}

The combination index $(\mathrm{CI})$ values of oxaliplatin and cetuximab in hypoxic or normoxic MGC803 and SGC7901 cells were calculated using the Median Dose-Effect program by Chou and Hayball as described in Materials and methods. CI values $<1$ indicate synergy. lines. MGC803 and SGC7901 cells were treated with oxaliplatin $(100 \mu \mathrm{M}, 200 \mu \mathrm{M})$, cetuximab $(50 \mu \mathrm{g} / \mathrm{ml})$, or the combination under normoxic or hypoxic conditions. After 24 or $48 \mathrm{~h}$, the percentage of apoptotic cells was quantified by flow cytometry analysis using annexin-V/PI double staining (Fig. 3). In addition to the controls set up with single agents, normoxia alone and hypoxia alone were also used as controls. Cetuximab treatment alone did not induce apoptosis in gastric cancer cell lines under either normoxic or hypoxic conditions. Oxaliplatin induced apoptosis in a dose- and time-dependent manner in both normoxic and hypoxic cells.

We demonstrated that hypoxia protected gastric cancer cells from oxaliplatin-induced apoptosis. Treatment of normoxic MGC803 cells with $100 \mu \mathrm{M}$ oxaliplatin resulted in 28 and $53 \%$ apoptosis at 24 and $48 \mathrm{~h}$ respectively, while cetuximab $(50 \mu \mathrm{g} / \mathrm{ml})$ and oxaliplatin $(100 \mu \mathrm{M})$ combination treatment resulted in 35 and $61 \%$ apoptosis at 24 and $48 \mathrm{~h}$, respectively (Fig. 3a). Hypoxic MGC803 cells treated with $100 \mu \mathrm{M}$ oxaliplatin exhibited 14 and $32 \%$ apoptosis at 24 and $48 \mathrm{~h}$ respectively, while cetuximab $(50 \mu \mathrm{g} / \mathrm{ml})$ and oxaliplatin $(100 \mu \mathrm{M})$ combination therapy resulted in 34 and $54 \%$ 
(a)
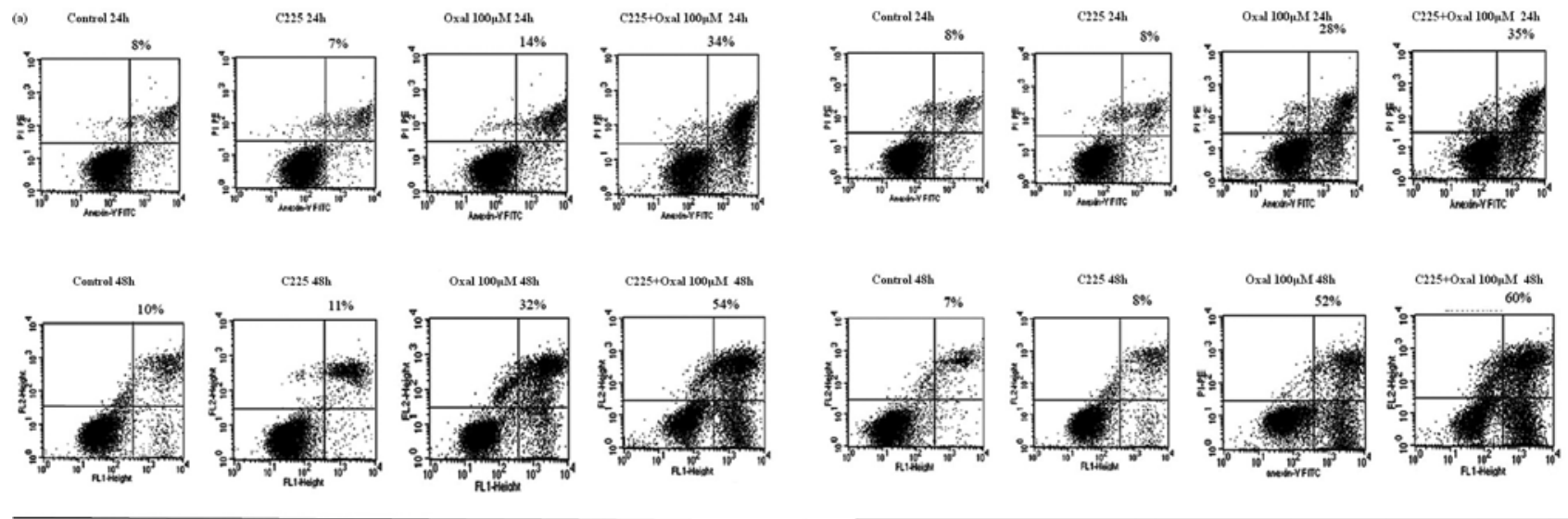

MOC 803 HYPOXIA

MGC 803 NORMOXIA

(b-1) MGC803 $24 \mathrm{~h}$

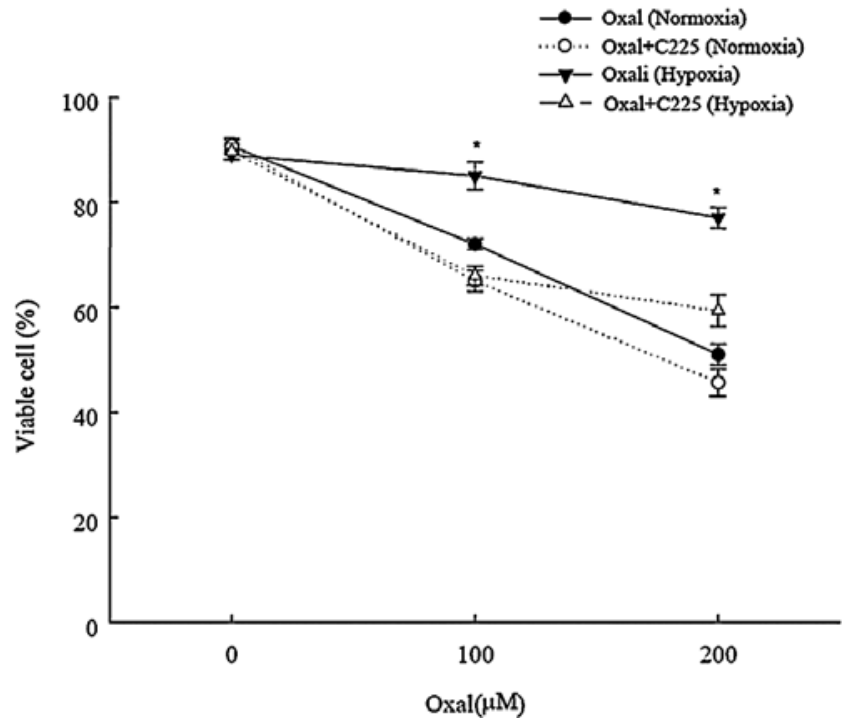

(b-2) MGC803 $48 \mathrm{~h}$

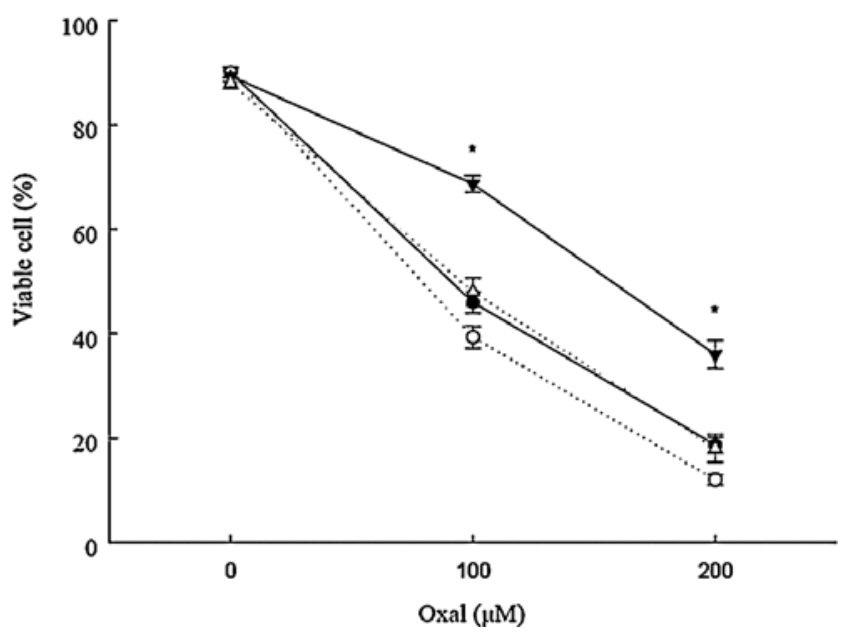

(c)
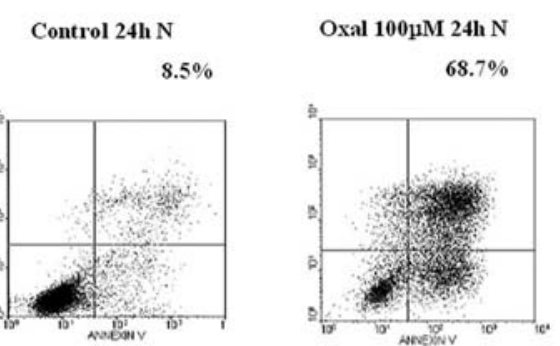

Control 24h H

$9.3 \%$

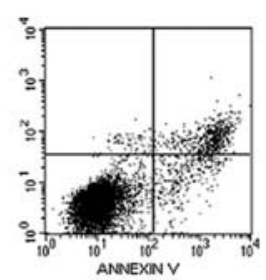

C225 24h H

$9 \%$

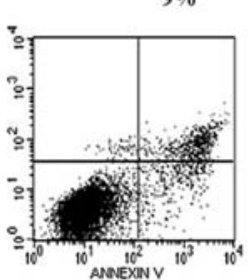

Oxal 100pM 24h H

$51.4 \%$

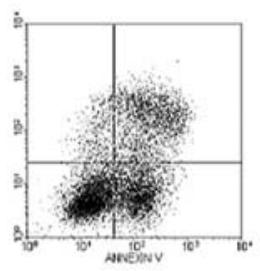

C225+ Oxal 100pM 24h H

$73 \%$

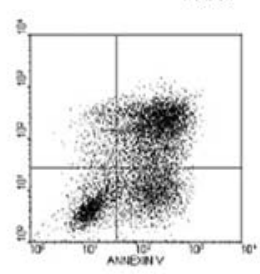

Figure 3. a-c. Synergistic effect of cetuximab and oxalibplatin on induction of apoptosis in human gastric cancer cells. 
(d-1) SGC7901 $24 \mathrm{~h}$

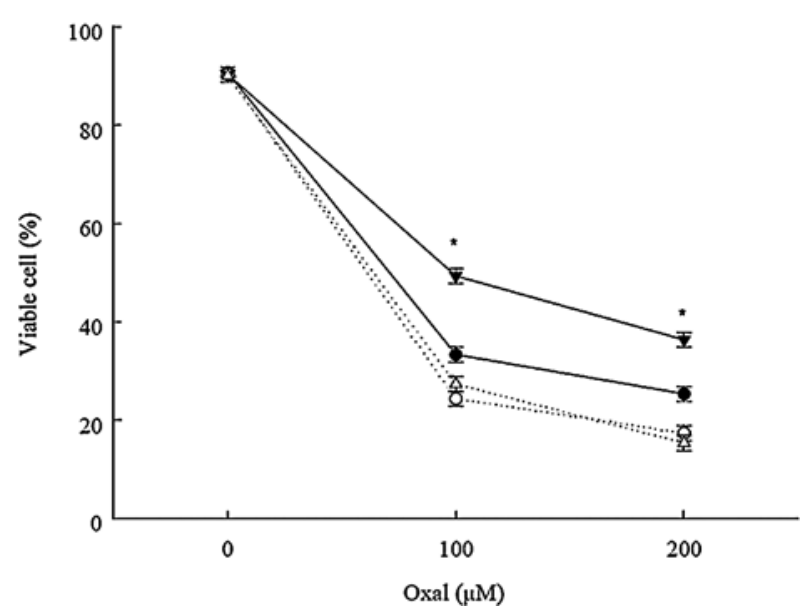

(d-2) SGC7901 $48 \mathrm{~h}$

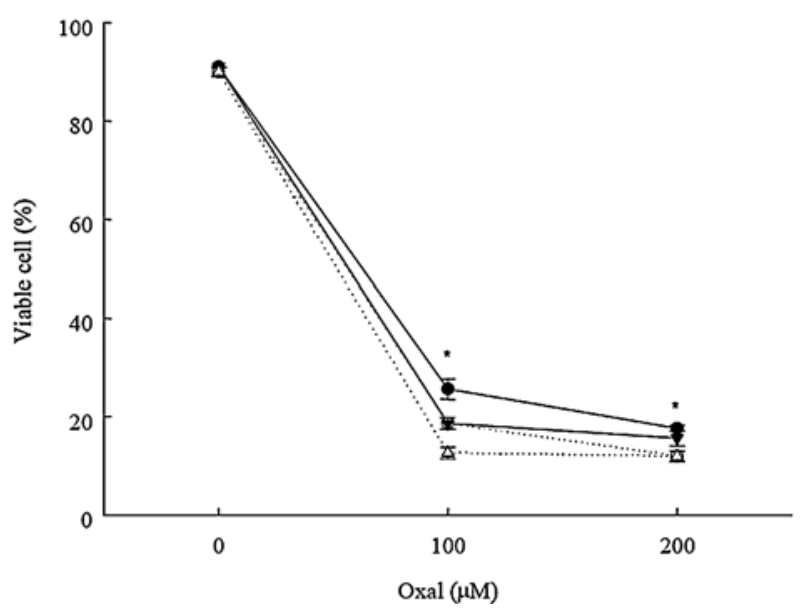

Figure 3. Synergistic effect of cetuximab and oxalibplatin on induction of apoptosis in human gastric cancer cells. Drug sensitivity of normoxic and hypoxic MGC803 cells (a and b) and normoxic and hypoxic SGC7901 cells (c and d) was compared. MGC803 cells were treated with oxaliplatin (100 and $200 \mu$ M), cetuximab $(50 \mu \mathrm{g} / \mathrm{ml})$, or their combinations as indicated. The cells were double stained with annexin-V and propidium iodide (PI) and apoptosis was measured by flow cytometry. Concentration-dependent loss of cell viability induced by oxaliplatin (100 and $200 \mu \mathrm{M})$ in the presence and absence of cetuximab $(50 \mu \mathrm{g} / \mathrm{ml}, 24 \mathrm{~h}, 48 \mathrm{~h})$ was determined in MGC803 cells and SGC7901 cells. Viable cells (annexin-V and PI negative) were expressed as percent of control. $\mathrm{N}$ denotes normoxia and $\mathrm{H}$ denotes hypoxia. Controls were set up in each group with either normoxia or hypoxia alone and treatment with single agents at the two different time points. Data are shown as mean \pm SD for (b-1) MGC803 cell at 24 h, (b-2) MGC803 cell at 48 h, (d-1) SGC7901 cell at 24 h, and (d-2) SGC7901 at $48 \mathrm{~h}$. The asterisk (*) indicates that the mean number of viable cells (\%) differed significantly between the group treated with oxaliplatin alone and the group treated with the oxaliplatin-cetuximab combination $(\mathrm{p}<0.001)$.

apoptosis at 24 and 48 h, respectively (Fig. 3b). We also showed that combination therapy enhanced oxaliplatin-induced apoptosis in normoxic and hypoxic SGC7901 cell lines (Fig. 3c and d). In summary, we showed that cetuximab-oxaliplatin combination treatment resulted in a higher percentage of apoptosis in hypoxic cells when compared with oxaliplatin treatment alone.

Effect of cetuximab and oxaliplatin on HIF-1a levels. In order to investigate the mechanism of cetuximab-mediated enhancement of apoptosis in oxaliplatin-treated hypoxic cells, we looked at the effect of cetuximab on the expression of HIF-1 $\alpha$. Gastric cancer cells were treated with cetuximab alone, oxaliplatin alone or the combination and HIF-1 $\alpha$ expression was examined by immunoblotting. As expected, we found increased levels of HIF-1 $\alpha$ expression in hypoxic cells (Fig. 4a) when compared with normoxic cells. Treatment of hypoxic cells with either cetuximab or oxaliplatin alone caused a moderate reduction in the expression levels of HIF-1 $\alpha$, but combination treatment caused an efficient inhibition of HIF-1 $\alpha$ expression in these cells.

Effect of cetuximab and oxaliplatin on EGFR signaling pathways. PI3-K/AKT/BAD and ERK/MAPK have been reported to be the two major pathways that interact with HIF-1 $\alpha$ (17-19) and are also the major intracellular downstream signaling pathways that are directly and indirectly activated in response to ligand-dependent EGFR activation. We therefore assessed the role of cetuximab and oxaliplatin on AKT and ERK1/2 phosphorylation in MGC803 cells. We demonstrated a slight reduction in the levels of phosphorylated AKT and phosphorylated ERK1/2 in normoxic and hypoxic cells treated with cetuximab. Treatment of these cells with oxaliplatin alone did not affect the phosphorylation of AKT and ERK1/2. Interestingly, oxaliplatin-cetuximab combination treatment resulted in efficient inhibition of p-AKT levels in both normoxic and hypoxic cells and of p-ERK1/2 levels in hypoxic cells (Fig. 4b and c). We found no change in the levels of total AKT and ERK1/2 in cetuximab-treated cells suggesting that cetuximab did not inhibit ERK1/2 and AKT synthesis.

The Bcl-2 family member BAD is an important proapoptotic downstream target of EGFR in mammary cells $(33,34)$. Since EGF-induced phosphorylation of BAD is known to occur via the MAPK and PI3-K pathway (35), we evaluated the role of cetuximab and oxaliplatin on phosphorylation of BAD in normoxic and hypoxic cells. We showed that cetuximab treatment caused a decrease in phospho-BAD levels in hypoxic cells, while the decrease was not as marked in normoxic cells (Fig. 4c). These data suggest that EGF-induced phosphorylation of BAD occurs mainly through the MAPK and PI3-K pathways in these cells and agree with previous work showing the effect of small molecule inhibitors of EGFR on p-BAD (34). Treatment with oxaliplatin alone did not affect phospho-BAD levels in either normoxic or hypoxic cells. However, cetuximab-oxaliplatin combination therapy resulted in significant inhibition of phospho-BAD levels in hypoxic cells, which was consistent with the synergistic effect of these two compounds. No changes were observed in the total expression levels of BAD and BAX proteins. From these data, we conclude that cetuximab-oxaliplatin combination treatment causes 1) inhibition of MAPK and PI3-K/AKT signaling downstream of EGFR 2) inhibition of HIF-1 $\alpha$ expression and ultimately 3 ) increased apoptosis in these cells.

Inhibition of hypoxia-induced expression of VEGF by cetuximab. VEGF, which is a downstream target of HIF-1 $\alpha$, 
(a)

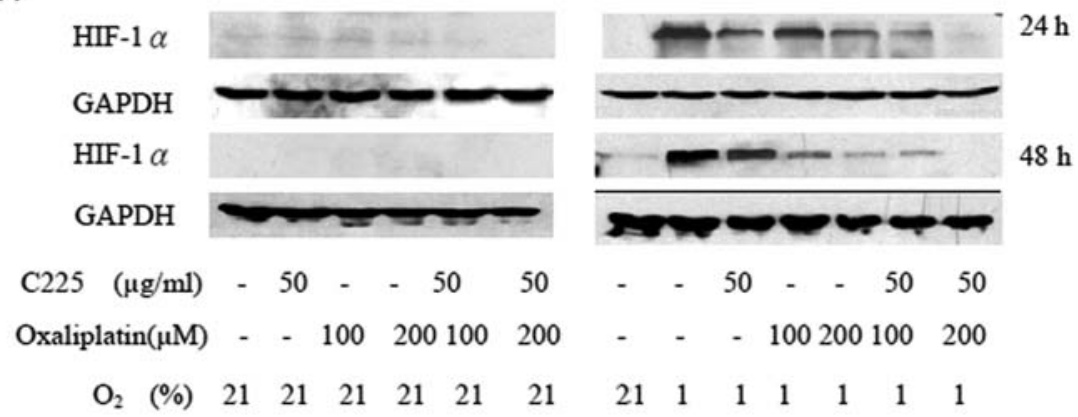

(b)
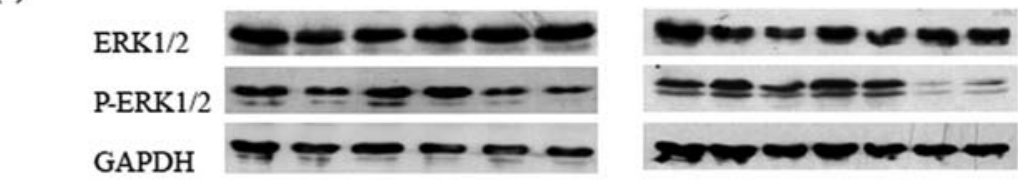

$\mathrm{C} 225(\mu \mathrm{g} / \mathrm{ml})-50 \quad-50 \quad 50$

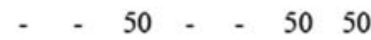

Oxaliplatin $(\mu \mathrm{M}) \quad-\quad-100200100200$

- $\quad-100200100200$

$\mathrm{O}_{2}(\%) \quad 21 \quad 21 \quad 21 \quad 21 \quad 21 \quad 21$

$\begin{array}{lllllll}21 & 1 & 1 & 1 & 1 & 1 & 1\end{array}$

(c)

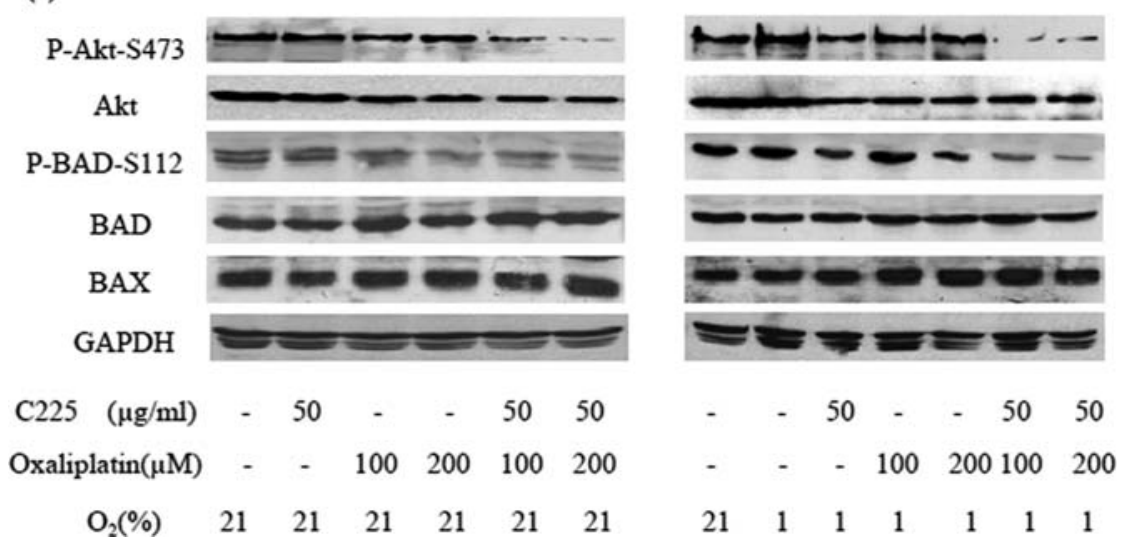

Figure 4. Effect of cetuximab-oxaliplatin treatment on expression levels of HIF-1 $\alpha$ and EGFR downstream signaling targets. (a) Reduction of HIF-1 $\alpha$ levels in cetuximab-oxaliplatin-treated MGC803 cells. (b) Inhibition of MAPK phosphorylation in cetuximab-oxaliplatin-treated MGC 803 cells. (c) Effect of cetuximab and oxaliplatin on phosphorylation of AKT downstream targets and on the expression of BAX under nomoxic and hypoxic conditions. MGC803 cell were left untreated or treated with cetuximab $(50 \mu \mathrm{g} / \mathrm{ml})$, oxaliplatin $(100 \mu \mathrm{M}, 200 \mu \mathrm{M})$ or the combination for $24 \mathrm{~h}$. Expression levels of HIF-1 $\alpha$, ERK, phospho-ERK1/2, AKT, phosphor-AKT, BAD, phosphor-BAD and BAX were determined by Western blot analysis using appropriate antibodies. GAPDH was also blotted as protein loading control.

plays an important role in tumorigenesis, tumor invasion, metastasis and drug-resistance induced by hypoxia (6-8). We used ELISA to assess expression levels of VEGF in hypoxic cetuximab-treated MGC803 and SGC7901 cells. Cells were treated with cetuximab $(50 \mu \mathrm{g} / \mathrm{ml})$, oxaliplatin $(100 \mu \mathrm{M}$, $200 \mu \mathrm{M})$ or a combination of both agents for 24 or $48 \mathrm{~h}$ under hypoxic or normoxic conditions as described above and VEGF levels were assayed. We showed that cetuximab, oxaliplatin, and different oxygen concentrations all influenced the expression of VEGF in both cell lines (Fig. 5). We showed that hypoxia resulted in a statistically significant increase in VEGF expression $(p<0.001)$. Treatment with cetuximab alone led to an inhibition of VEGF expression in hypoxia as well as normoxia. Treatment with oxaliplatin alone also led to an inhibition of VEGF in a dose-dependent manner. Combination treatment had a synergistic effect on inhibition of VEGF expression in normoxia as well as hypoxia, although the inhibition was more pronounced in hypoxia.

\section{Discussion}

The HIF-1 $\alpha$ pathway has impacted current treatment strategies of solid tumors such as gastric cancer since hypoxia in tumors is associated with poor prognosis and resistance to chemotherapy $(14,15,36,37)$.

Our results were in accord with previous studies $(38,39)$ that hypoxia caused a significant upregulation in the expression level of HIF-1 $\alpha$ with a simultaneous increase in drug resistance of gastric cancer cells. Expression levels of HIF- $1 \alpha$ are known to be upregulated by activation of EGFR signaling via the PI3-K/AKT and MAPK/ERK pathways $(11,17-19,40)$. Our results were in accord with previous studies 
(a-1)

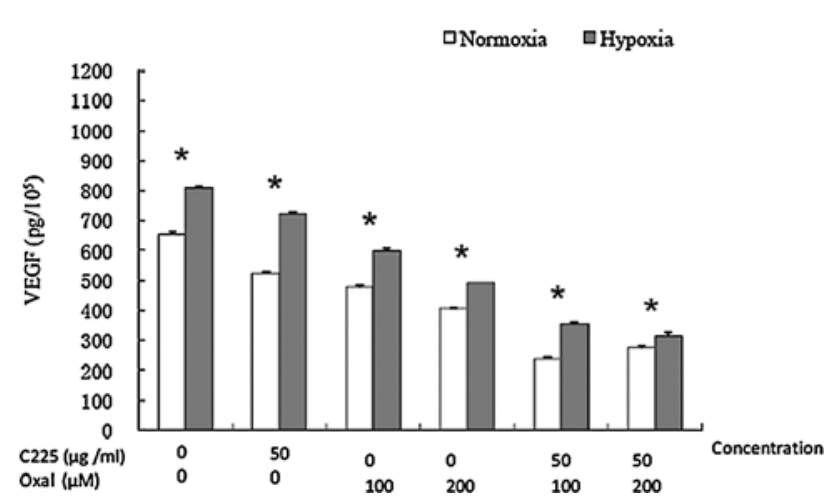

(b-1)

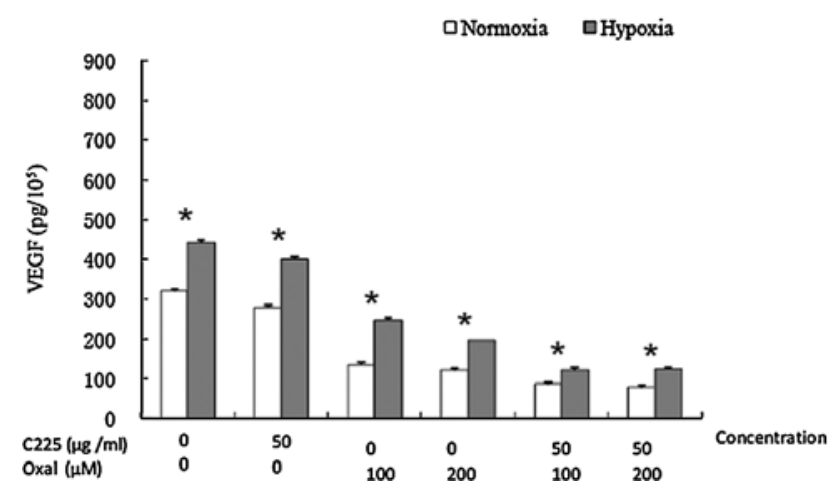

$(\mathrm{a}-2)$

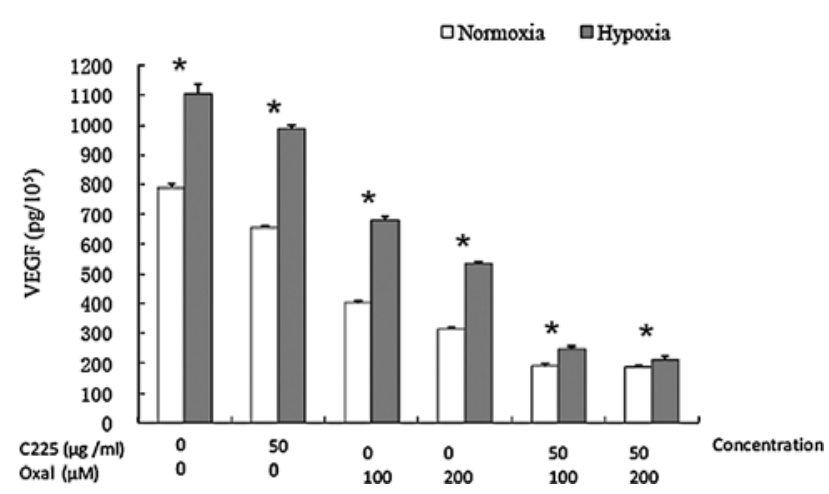

(b-2)

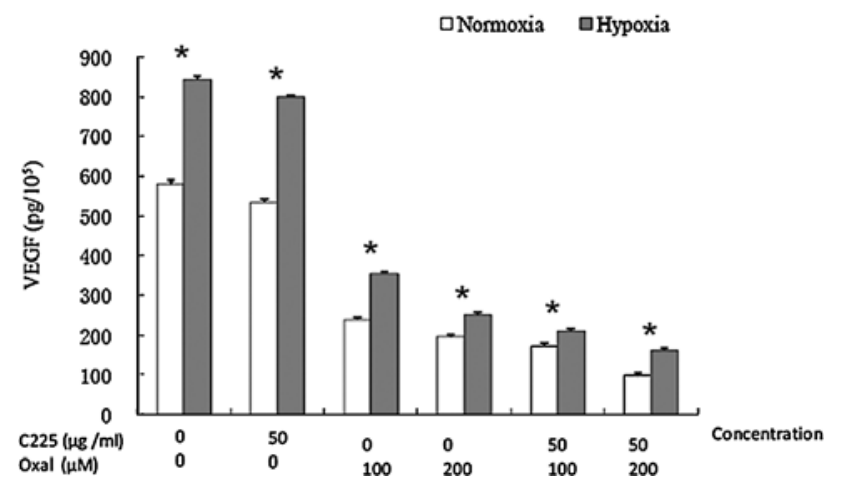

Figure 5. Cetuximab inhibits VEGF expression in normoxia as well as in hypoxia. Data are shown as the mean (SD) for (a-1) MGC803 cells at 24 h, (a-2) MGC803 cells at 48 h, (b-1) SGC7901 cells at 24 h, and (b-2) SGC7901 cells at 48 h. Using ANOVA, we found significant differences in the average overall expression of VEGF between normoxic and hypoxic MG803 as well as SGC7901 cells, at 24 or $48 \mathrm{~h}$ follow-up after treatment (p<0.001 for MGC803 cells at $24 \mathrm{~h}$, MGC803 cells at $48 \mathrm{~h}$, SGC7901 cells at $24 \mathrm{~h}$, and SGC7901 cells at $48 \mathrm{~h}$ ).

showing that blockade of EGFR pathways by cetuximab inhibited the expression of HIF-1 $\alpha$ in hypoxia $(25,29,41-45)$. We showed that cetuximab-mediated down-regulation of ERK1/2 and AKT phosphorylation, especially in hypoxic gastric cancer cells, led to the downstream inhibition of HIF-1 $\alpha$. Although our results are not direct evidence, they suggest that cetuximab-oxaliplatin treatment results in decreased expression of HIF-1 $\alpha$ which leads to enhanced apoptosis of hypoxic gastric cancer cells. We plan to use siRNA-mediated HIF-1 $\alpha$ silencing or generate HIF-1 $\alpha$ null cell lines in order to further support our conclusion.

Oxaliplatin-cetuximab combination therapy resulted in more significantly cytotoxic effects in hypoxic gastric cancer cells than in normoxic cells. We showed that hypoxia protected gastric cancer cells from oxaliplatin-induced apoptosis. Treatment of hypoxic cells with a cetuximab-oxaliplatin combination treatment resulted in more intense induction of apoptosis when compared with normoxic cells.

Recent studies showed that blocking EGFR and the downstream MAPK and PI3-K activity led to a decrease in Ser ${ }^{112}$ phosphorylation of BAD and subsequent induction of apoptosis (36). Our data showed that decreased AKT and ERK1/2 phosphorylation and decreased Ser ${ }^{112}$ phosphorylation of BAD (Fig. 4c) were associated with enhanced oxaliplatin-cetuximab induced apoptosis. Our data indicated that phospho-BAD levels decreased more significantly in oxaliplatin-cetuximab treated hypoxic cells, than in oxaliplatincetuximab treated normoxic cells. pBAD is known to associate with 14-3-3 leading to cell survival and is down-regulated in a HIF-1 $\alpha$-independent manner in several different hypoxic cell lines (46). Inhibition of BAD phosphorylation leads to a physical association of BAD with $\mathrm{Bcl}-\mathrm{xl}$ and results in increased apoptosis $(34,35)$. We propose that oxaliplatincetuximab combination therapy acts via inhibition of BAD phosphorylation in order to promote apoptosis in hypoxic cells. Our results were in accord with previous studies $(11,46)$ that the inhibitory effect exerted by cetuximab on BAD phosphorylation was more significant in hypoxia than in normoxia. In summary, our results lead us to speculate that cetuximab enhances oxaliplatin-mediated apoptosis by reducing HIF-1 $\alpha$ expression and p-BAD levels via inhibition MAPK and PI3-K/ AKT signaling downstream of EGFR.

Angiogenesis in hypoxia is a critical step in the pathogenesis of most cancers. VEGF has been identified as one of the key growth factors mediating this process and is a primary transcriptional target of HIF-1 (6-8). There is growing evidence $(27,47-49)$ that growth factors and hypoxia act by enhancing the translation and stability of HIF- $1 \alpha$ via activation of MAPK or PI3K/AKT pathways which in turn regulate VEGF expression. Our data showed that cetuximab-mediated inhibition of AKT and ERK1/2 phosphorylation resulted in decreased HIF-1 $\alpha$ expression and a subsequent inhibition of 
VEGF expression. Combination treatment with cetuximab and oxaliplatin resulted in an even greater inhibition of hypoxiainduced expression of VEGF than oxaliplatin treatment alone. Our data are in agreement with previous studies that inhibition of EGFR by monoclonal antibodies led to reduced expression of VEGF and inhibition of angiogenesis $(7,8,24,27,49)$. It is important to investigate if VEGF inhibition by cetuximaboxaliplatin combination therapy in our system translates to a similar synergistic effect in clinical situations.

Cetuximab was recently used in a clinical trial in combination with a modified version of FOLFOX6 to treat gastric cancer (50). Not surprisingly, this study showed that patients with EGFR expression and low levels of competitive ligands (EGF and $\mathrm{TGF} \alpha$ ) had a $100 \%$ response rate. Biomarkers such as these, which can be used to optimize treatment strategies make molecules like cetuximab especially attractive in the treatment of aggressive diseases such as gastric cancer.

In conclusion, we showed that cetuximab played an important role in overcoming hypoxia-mediated drug resistance in gastric cancer cell lines. We propose a novel mechanism whereby cetuximab-oxaliplatin combination therapy results in a reduction of HIF- $1 \alpha$ protein synthesis via MAPK/ERK and PI3-K/AKT pathways leading to a subsequent inhibition of VEGF expression. To our knowledge, we are the first to demonstrate potentiation of oxaliplatin by cetuximab via inhibition of BAD phosphorylation leading to increased apoptosis in hypoxic gastric cancer cells. Our findings also provide a molecular basis in using oxaliplatincetuximab combination treatment to improve clinical outcomes in gastric cancer. Our future goals include establishing xenografts of gastric cancer cells to assess the efficacy of the cetuximab-oxaliplatin combination in vivo.

\section{Acknowledgements}

This study was supported by National Natural Science Foundation of China grant 30672408, Guangzhou Bureau of Science and Technology grant 2006Z3-E0041 and Sun Yat-sen University 985 Program Initiation Fund (China).

\section{References}

1. Parkin DM, Bray F, Ferlay $J$ and Pisani P: Global cancer statistics, 2002. CA Cancer J Clin 55: 74-108, 2005.

2. Varadhachary G and Ajani JA: Gastric cancer. Clin Adv Hematol Oncol 3: 118-124, 2005.

3. Karpeh MS, Kelsen DP and Tepper JE: Cancer Principles and Practice of Oncology. Lippincott Williams and Wilkins, Philadelphia, PA, 2001.

4. Wang GL, Jiang BH, Rue EA and Semenza GL: Hypoxiainducible factor 1 is a basic-helix-loop-helix-PAS heterodimer regulated by cellular $\mathrm{O}_{2}$ tension. Proc Natl Acad Sci USA 92: 5510-5514, 1995.

5. Semenza GL and Wang GL: A nuclear factor induced by hypoxia via de novo protein synthesis binds to the human erythropoietin gene enhancer at a site required for transcriptional activation. Mol Cell Biol 12: 5447-5454, 1992.

6. Forsythe JA, Jiang BH, Iyer NV, Agani IF, Leung SW, Koos RD and Semenza GL: Activation of vascular endothelial growth factor gene transcription by hypoxia-inducible factor 1 . Mol Cell Biol 16: 4604-4613, 1996.

7. Karashima T, Sweeney P, Slaton JW, Kim SJ, Kedar D, Izawa JI, Fan Z, Pettaway C, Hicklin DJ, Shuin T and Dinney CP: Inhibition of angiogenesis by the antiepidermal growth factor receptor antibody ImClone $\mathrm{C} 225$ in androgen-independent prostate cancer growing orthotopically in nude mice. Clin Cancer Res 8: 1253-1264, 2002.
8. Ciardiello F, Bianco R, Damiano V, Fontanini G, Caputo R, Pomatico G, De Placido S, Bianco AR, Mendelsohn J and Tortora G: Antiangiogenic and antitumor activity of antiepidermal growth factor receptor C225 monoclonal antibody in combination with vascular endothelial growth factor antisense oligonucleotide in human GEO colon cancer cells. Clin Cancer Res 6: 3739-3747, 2000

9. O'Rourke JF, Dachs GU, Gleadle JM, Maxwell PH, Pugh CW, Stratford IJ, Wood SM and Ratcliffe PJ: Hypoxia response elements. Oncol Res 9: 327-332, 1997.

10. Pugh CW and Ratcliffe PJ: Regulation of angiogenesis by hypoxia: role of the HIF system. Nat Med 9: 677-684, 2003.

11. Semenza GL: HIF-1 and tumor progression: pathophysiology and therapeutics. Trends Mol Med 8: S62-S67, 2002.

12. Pugh CW, O'Rourke JF, Nagao M, Gleadle JM and Ratcliffe PJ: Activation of hypoxia-inducible factor-1; definition of regulatory domains within the alpha subunit. J Biol Chem 272: 11205-11214, 1997.

13. Maxwell PH, Wiesener MS, Chang GW, Clifford SC, Vaux EC, Cockman ME, Wykoff CC, Pugh CW, Maher ER and Ratcliffe PJ: The tumour suppressor protein VHL targets hypoxia-inducible factors for oxygen-dependent proteolysis. Nature 399: 271-275, 1999.

14. Zhong H, De Marzo AM, Laughner E, Lim M, Hilton DA, Zagzag D, Buechler P, Isaacs WB, Semenza GL and Simons JW: Overexpression of hypoxia-inducible factor 1alpha in common human cancers and their metastases. Cancer Res 59: 5830-5835, 1999.

15. Höckel $\mathrm{M}$ and Vaupel P: Tumor hypoxia: definitions and current clinical, biologic, and molecular aspects. J Natl Cancer Inst 93: 266-276, 2001.

16. Mellinghoff IK, Cloughesy TF and Mischel PS: PTEN-mediated resistance to epidermal growth factor receptor kinase inhibitors. Clin Cancer Res 13: 378-381, 2007.

17. Semenza GL: Regulation of mammalian $\mathrm{O}_{2}$ homeostasis by hypoxia-inducible factor 1 . Annu Rev Cell Dev Biol 15: 551-578, 1999.

18. Sang N, Stiehl DP, Bohensky J, Leshchinsky I, Srinivas V and Caro J: MAPK signaling up-regulates the activity of hypoxiainducible factors by its effects on p300. J Biol Chem 278: 14013-14019, 2003.

19. Fukuda R, Hirota K, Fan F, Jung YD, Ellis LM and Semenza GL: Insulin-like growth factor 1 induces hypoxia-inducible factor 1mediated vascular endothelial growth factor expression, which is dependent on MAP kinase and phosphatidylinositol 3-kinase signaling in colon cancer cells. J Biol Chem 277: 38205-38211, 2002.

20. Mendelsohn $\mathrm{J}$ and Baselga J: The EGF receptor family as targets for cancer therapy. Oncogene 19: 6550-6565, 2000.

21. Bogdan S and Klämbt C: Epidermal growth factor receptor signaling. Curr Biol 11: R292-R295, 2001.

22. Schlessinger J: Cell signaling by receptor tyrosine kinases. Cell 103: 193-200, 2000.

23. Goldstein NI, Prewett M, Zuklys K, Rockwell P and Mendelsohn J: Biological efficacy of a chimeric antibody to the epidermal growth factor receptor in a human tumor xenograft model. Clin Cancer Res 1: 1311-1318, 1995.

24. Huang SM, Li J, Armstrong EA and Harari PM: Modulation of radiation response and tumor-induced angiogenesis after epidermal growth factor receptor inhibition by ZD1839 (Iressa). Cancer Res 62: 4300-4306, 2002.

25. Luwor RB, Lu Y, Li X, Mendelsohn J and Fan Z: The antiepidermal growth factor receptor monoclonal antibody cetuximab/ C225 reduces hypoxia-inducible factor-1 alpha, leading to transcriptional inhibition of vascular endothelial growth factor expression. Oncogene 24: 4433-4441, 2005.

26. Li X, Lu Y, Liang K, Pan T, Mendelsohn J and Fan Z: Requirement of hypoxia-inducible factor-1alpha downregulation in mediating the antitumor activity of the antiepidermal growth factor receptor monoclonal antibody cetuximab. Mol Cancer Ther 7: 1207-1217, 2008.

27. Pore N, Jiang Z, Gupta A, Cerniglia G, Kao GD and Maity A: EGFR tyrosine kinase inhibitors decrease VEGF expression by both hypoxia-inducible factor (HIF)-1-independent and HIF-1dependent mechanisms. Cancer Res 66: 3197-3204, 2006.

28. Prewett MC, Hooper AT, Bassi R, Ellis LM, Waksal HW and Hicklin DJ: Enhanced antitumor activity of anti-epidermal growth factor receptor monoclonal antibody IMC-C225 in combination with irinotecan (CPT-11) against human colorectal tumor xenografts. Clin Cancer Res 8: 994-1003, 2002. 
29. Balin-Gauthier D, Delord JP, Rochaix P, Mallard V, Thomas F, Hennebelle I, Bugat R, Canal P and Allal C: In vivo and in vitro antitumor activity of oxaliplatin in combination with cetuximab in human colorectal tumor cell lines expressing different level of EGFR. Cancer Chemother Pharmacol 57: 709-718, 2006.

30. Baselga J, Norton L, Masui H, Pandiella A, Coplan K, Miller WH Jr and Mendelsohn J: Antitumor effects of doxorubicin in combination with anti-epidermal growth factor receptor monoclonal antibodies. J Natl Cancer Inst 85: 1327-1333, 1993

31. Inoue K, Slaton JW, Perrotte P, Davis DW, Bruns CJ, Hicklin DJ, McConkey DJ, Sweeney P, Radinsky R and Dinney CP: Paclitaxel enhances the effects of the anti-epidermal growth factor receptor monoclonal antibody ImClone C225 in mice with metastatic human bladder transitional cell carcinoma. Clin Cancer Res 6: 4874-4884, 2000.

32. Chou TC and Talalay P: Quantitative analysis of dose-effect relationships: the combined effects of multiple drugs or enzyme inhibitors. Adv Enzyme Regul 22: 27-55, 1984.

33. Zhou XM, Liu Y, Payne G, Lutz RJ and Chittenden T: Growth factors inactivate the cell death promoter BAD by phosphorylation of its BH3 domain on Ser155. J Biol Chem 275: 25046-25051, 2000

34. Gilmore AP, Valentijn AJ, Wang P, Ranger AM, Bundred N, O'Hare MJ, Wakeling A, Korsmeyer SJ and Streuli CH: Activation of BAD by therapeutic inhibition of epidermal growth factor receptor and transactivation by insulin-like growth factor receptor. J Biol Chem 277: 27643-27650, 2002.

35. Fang X, Yu S, Eder A, Mao M, Bast RC, Boyd JD and Mills GB: Regulation of BAD phosphorylation at serine 112 by the Rasmitogen-activated protein kinase pathway. Oncogene 18: 6635-6640, 1999

36. Gray LH, Conger AD, Ebert M, Hornsey S and Scott OC: The concentration of oxygen dissolved in tissues at the time of irradiation as a factor in radiotherapy. Br J Radiol 26: 638-648, 1953

37. Ciardiello F, Bianco R, Damiano V, De Lorenzo S, Pepe S, De Placido S, Fan Z, Mendelsohn J, Bianco AR and Tortora G: Antitumor activity of sequential treatment with topotecan and anti-epidermal growth factor receptor monoclonal antibody C225. Clin Cancer Res 5: 909-916, 1999.

38. Teicher BA: Hypoxia and drug resistance. Cancer Metastasis Rev 13: 139-168, 1994.

39. Yokoi K and Fidler IJ: Hypoxia increases resistance of human pancreatic cancer cells to apoptosis induced by gemcitabine. Clin Cancer Res 10: 2299-2306, 2004.

40. Comerford KM, Cummins EP and Taylor CT: c-Jun NH2terminal kinase activation contributes to hypoxia-inducible factor 1alpha-dependent P-glycoprotein expression in hypoxia. Cancer Res 64: 9057-9061, 2004.

41. Fan Z, Baselga J, Masui H and Mendelsohn J: Antitumor effect of anti-epidermal growth factor receptor monoclonal antibodies plus cis-diamminedichloroplatinum on well established A431 cell xenografts. Cancer Res 53: 4637-4642, 1993.
42. Fan Z, Masui H, Altas I and Mendelsohn J: Blockade of epidermal growth factor receptor function by bivalent and monovalent fragments of 225 anti-epidermal growth factor receptor monoclonal antibodies. Cancer Res 53: 4322-4328, 1993.

43. Bruns CJ, Harbison MT, Davis DW, Portera CA, Tsan R McConkey DJ, Evans DB, Abbruzzese JL, Hicklin DJ and Radinsky R: Epidermal growth factor receptor blockade with C225 plus gemcitabine results in regression of human pancreatic carcinoma growing orthotopically in nude mice by antiangiogenic mechanisms. Clin Cancer Res 6: 1936-1948, 2000.

44. Huang SM, Bock JM and Harari PM: Epidermal growth factor receptor blockade with C225 modulates proliferation, apoptosis, and radiosensitivity in squamous cell carcinomas of the head and neck. Cancer Res 59: 1935-1940, 1999.

45. Tortora G, Caputo R, Pomatico G, Pepe S, Bianco AR, Agrawal S, Mendelsohn J and Ciardiello F: Cooperative inhibitory effect of novel mixed backbone oligonucleotide targeting protein kinase A in combination with docetaxel and anti-epidermal growth factorreceptor antibody on human breast cancer cell growth. Clin Cancer Res 5: 875-881, 1999.

46. Erler JT, Cawthorne CJ, Williams KJ, Koritzinsky M, Wouters BG, Wilson C, Miller C, Demonacos C, Stratford IJ and Dive C: Hypoxia-mediated down-regulation of Bid and Bax in tumors occurs via hypoxia-inducible factor 1-dependent and independent mechanisms and contributes to drug resistance. Mol Cell Biol 24: 2875-2889, 2004.

47. Laughner E, Taghavi P, Chiles K, Mahon PC and Semenza GL: HER2 (neu) signaling increases the rate of hypoxia-inducible factor 1alpha (HIF-1alpha) synthesis: novel mechanism for HIF-1mediated vascular endothelial growth factor expression. Mol Cell Biol 21: 3995-4004, 2001.

48. Perrotte P, Matsumoto T, Inoue K, Kuniyasu H, Eve BY, Hicklin DJ, Radinsky R and Dinney CP: Anti-epidermal growth factor receptor antibody C225 inhibits angiogenesis in human transitional cell carcinoma growing orthotopically in nude mice. Clin Cancer Res 5: 257-265, 1999.

49. Petit AM, Rak J, Hung MC, Rockwell P, Goldstein N, Fendly B and Kerbel RS: Neutralizing antibodies against epidermal growth factor and ErbB-2/neu receptor tyrosine kinases downregulate vascular endothelial growth factor production by tumor cells in vitro and in vivo: angiogenic implications for signal transduction therapy of solid tumors. Am J Pathol 151: 1523-1530, 1997.

50. Han SW, Oh DY, Im SA, Park SR, Lee KW, Song HS, Lee NS, Lee KH, Choi IS, Lee MH, Kim MA, Kim WH, Bang YJ and Kim TY: Phase II study and biomarker analysis of cetuximab combined with modified FOLFOX6 in advanced gastric cancer. Br J Cancer 100: 298-304, 2009. 